\title{
Circular Economy: Challenges and Opportunities in the Construction Sector of Kazakhstan
}

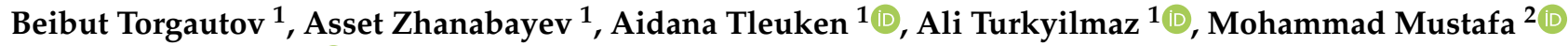 \\ and Ferhat Karaca $1, *$ (i)
}

1 Department of Civil and Environmental Engineering, School of Engineering and Digital Sciences, Nazarbayev University, 53 Kabanbay Batyr Av., Nur-Sultan 010000, Kazakhstan; beibut.torgautov@alumni.nu.edu.kz (B.T.); asset.zhanabayev@alumni.nu.edu.kz (A.Z.); aidana.tleuken@nu.edu.kz (A.T.); ali.turkyilmaz@nu.edu.kz (A.T.)

2 Institute of Buildings, Energy and Material Technology, Faculty of Engineering Science and Technology, The Arctic University of Norway, 9019 Tromsø, Norway; mohamad.y.mustafa@uit.no

* Correspondence: ferhat.karaca@nu.edu.kz; Tel.: +7-7172-704553; Fax: +7-7172-706054

Citation: Torgautov, B.; Zhanabayev,

A.; Tleuken, A.; Turkyilmaz, A.;

Mustafa, M.; Karaca, F. Circular

Economy: Challenges and

Opportunities in the Construction

Sector of Kazakhstan. Buildings 2021,

11, 501. https://doi.org/10.3390/

buildings 11110501

Academic Editor: Cinzia Buratti

Received: 13 September 2021

Accepted: 17 October 2021

Published: 24 October 2021

Publisher's Note: MDPI stays neutral with regard to jurisdictional claims in published maps and institutional affiliations.

Copyright: (c) 2021 by the authors. Licensee MDPI, Basel, Switzerland. This article is an open access article distributed under the terms and conditions of the Creative Commons Attribution (CC BY) license (https:// creativecommons.org/licenses/by/ $4.0 /)$.

\begin{abstract}
The circular economy in the construction sector in emerging economies is one of the most promising concepts that aims to keep the value of the construction materials and structures as long as possible. The construction industry is rapidly developing in Kazakhstan with a yearly increase in projects. This research paper investigates the construction sector in Kazakhstan in terms of the potential application of circular economy principles by local stakeholders-clients, contractors, designers, and manufacturers. As limited research has been conducted on the circularity within the construction environment, including construction parties, this paper aims to fill this research gap. It seeks to identify the construction trends and perform a barrier and opportunity analysis to develop circular economy principles in the construction sector. As a research method, PEST is used for the study of local construction trends. At the same time, stakeholders are interviewed using semistructured surveys organized according to the ReSOLVE framework (regenerate, share, optimize, loop, virtualize, and exchange) to identify the barriers and opportunities for circular economy in the construction sector. As an outcome of this study, the most common barriers and opportunities were associated with the economic benefit factor, as this was the main motivation for the stakeholders to save construction materials for reuse or to refuse more eco-friendly technologies. Additionally, policy recommendations for companies involved in the construction ecosystem were provided according to the assessment of found barriers and opportunities in the context of the ReSOLVE framework. This analysis has shown that for most stakeholders of the Kazakhstani construction sector, virtualization is of the highest priority; therefore, opportunities for its development are recommended. Future research could focus on the development of economically feasible solutions for the circular economy in construction with the inclusion of virtualization technologies.
\end{abstract}

Keywords: green building; sustainable construction; project delivery; ReSOLVE; PEST; construction and demolition waste; stakeholders' interview; design for disassembly; BIM

\section{Introduction}

Circular economy (CE) in the construction sector is an innovative business model concept emerging due to increasing concern towards keeping and restoring the value of construction materials and structures and minimizing construction and demolition waste (C\&DW). The primary purpose of $C E$ is to save the value of buildings and their components and eliminate the C\&DW as much as possible [1]. It comprises the whole life-cycle of the building construction process, starting from building design, building materials and components production, building use, and end-of-use demolition. Promoting principles of "cradle-to-cradle," the circular economy contrasts with the conventional linear economy by designing the building for repair and recycling in the initial design stage. Thus, CE 
promises to reduce carbon emissions [2] and make resources and energy consumption more efficient [3].

CE principles cover such aspects as reuse of materials, optimization of supply chain and a number of needed materials, improving planning and design stage, applying new eco-friendly technologies. Thus, it has a great potential to reduce carbon emissions and total waste from the construction industry. Some popular CE applications in construction projects include reduction of carbon embodied materials, use of lighter materials in construction, use of pulverized fuel ash and ground granulated blast furnace slag as a replacement for cement [4]; re-utilization of several smaller buildings into one large building, use of wooden materials and façade from older buildings, application of modular construction principle using steel from old buildings, and use of solar panels; use of locally abundant biomaterials; use of 100\% recycled and recyclable PVC plastic from shredded electric cable covers, pipes, and hose, construction on the contaminated lands, employment of greywater recovery from bath and shower systems; construction of a new building alongside the existing one using blocks that are easily disassembled and rebuilt after building life span [5]. Nevertheless, current practical research is limited by the prevailing recycling opportunities of C\&DW, while the waste's reuse portion is still low [3]. Therefore, most of the construction waste loses its value rather than continuing to be reused.

Several studies that assessed the level of awareness on circular economy principles present distinct results in the level of CE awareness and practices spread among the professionals in the construction industry. For example, a study by Adams et al. [3] found that although individual construction professionals are claimed to be aware of the circular economy, there is still a lack of general agreement on factors that lead to $\mathrm{CE}$ at the industry level [3]. In another example, Chang and Hsieh (2019), in their study on the awareness level of local construction stakeholders in Taiwan, revealed that principles of circularity appeared to be very relevant for a large number of the stakeholders involved in the design stage, while manufacturers put comparatively lesser attention to CE [5]. Whereas in the US, it was found that construction parties already adopt some CE practices, such as open-loop recycling and prefabrication, while closed-loop recycling and design for disassembly yet are hard to adopt $[6,7]$.

Kazakhstan is a developing country experiencing a rapid urbanization process. There is a trend of increase of urban population by the movement of people from rural areas. That fact leads to an increase in demand for living areas. The development of the construction industry during the last two decades has contributed to a rise in the production of construction materials by more than three times [8]. The production of construction materials in Kazakhstan takes second place among the largest industrial sectors. Most construction material manufacturers are engaged in producing concrete, cement, gypsum, and materials from clay and stones. Many manufacturing organizations for construction materials are located in the two largest cities, Almaty (including the Almaty region) and Nur-Sultan. Nevertheless, construction and demolition waste management (C\&DWM) is far removed from the official ideal levels. Construction waste is primarily made up of potentially reusable or recyclable materials (inert $(60 \%)$ and non-inert $(35 \%)$ ), with just $5 \%$ having to be disposed of in a landfill. Despite the fact that $95 \%$ of the waste may be recycled or repurposed, the majority of it is now disposed of in landfills. The enormous volume of inert trash, which accounts for more than half of all produced garbage, suggests a significant potential for reuse or recycling [9].

At the same time, the construction sector tends to increase the digitalization level. Thus, the "E-Kurylys" system was developed-the unified information system representing one of the tools for enhancing the quality control and transparency of construction processes in the country [10]. The system covers all stages of the construction process in all regions of Kazakhstan, providing access to technical documentation. In addition, this unified system will provide access to fire safety, sanitary, epidemiological, and other interested authorities to implement safety control. The introduction of the "E-Kurylys" system allows (1) supervising digital technical reports, (2) identifying nonconformities 
with the construction requirement, and controlling construction deadlines by significantly reducing paperwork.

Moreover, the government encourages the application of building information modeling (BIM) technologies to optimize the processes and improve the efficiency of construction works in Kazakhstan. In 2021, it is planned to increase the construction activities to introduce $17 \mathrm{M} \mathrm{m}^{2}$ of affordable social housing to be rented or purchased within the realization of the "Nurly Zher" state program. The government encourages the increase of construction volumes and improvement of the construction mechanism for affordable housing by attracting private investments [11].

Although the construction sector develops rapidly, it is still facing a gap in following circular economy principles. Thus, talking about $3 \mathrm{R}$ strategies towards construction and demolition waste, Kazakhstan still fails to reach fair applications of reducing, reusing, and recycling the construction waste [9]. For example, for the reduction of waste creation, an innovative factory for prefabricated building structures has started its operation recently [12], but for reuse and recycling, the technology advancement still needed to be developed [9]. Sustainability and circularity are not prioritized in the business processes, as economic profit is the main driver in decision-making. The largest city of Kazakhstan-Almaty-an economic and cultural center, has experienced the first circular economy analysis in Central Asia [13]. During that, it has been found that the industry does not utilize the full potential of preventing waste creation and recycling. The residential buildings sector is also blamed for large greenhouse gas emissions, extensive energy use, and detrimental effects on air and citizens' health [14]. Another study focusing on Almaty predicted that utilization of building materials with low carbon trace and optimization of the energy use could decrease current energy losses by more than $20 \%$. Residential building renovation and insulation enhancement can reduce the heat demand up to $45 \%$ [15]. Thus, the current review of the available literature on CE in Kazakhstan addresses the research gaps on the main drivers, prospects, and possible advantages, as limited research has been conducted within the framework of the actual construction environment and with the inclusion of the interested parties.

This study aims to identify the construction trends in Kazakhstan for their alignment towards the circular economy and assesses them from political, economic, social, and technological points of view. As a first time in Central Asia, it has an objective to perform a barrier and opportunity analysis to the circular economy actions and propose relevant policies for better development of the circularity in the construction sector.

This paper is organized as follows: firstly, the methodology utilized for this study is given in detail. It is followed by the Results section that includes the analysis of the construction trends and outcomes of the stakeholders' interviews. Later, in the Discussion section, the barrier and opportunity analysis is performed, leading the study to develop policy recommendations.

\section{Methods}

\subsection{Context of the Study}

The current paper acquires several methods to identify the construction trends and execute a barrier and opportunity analysis. It focuses on the analysis of the Kazakhstani construction sector's involved parties. All the participants of the survey interview are representatives of different construction companies $(n=18)$ of different sizes that perform various activities in the building sector, e.g., client, manufacturing, architectural design, and contracting activities.

\subsection{Data Collection}

The data was collected using either oral or written interviews. The questionnaire contained nine questions, which have been prepared according to the Guidelines for Research Ethics in Science and Technology and Procedures for Interview and Data Protection of Norwegian Arctic University (UiT). The questions assess the implementation of circular 
economy in terms of the ReSOLVE (regenerate, share, optimize, loop, virtualize, exchange) framework (for a detailed description of each element, see Table 1). This framework provides six key actions that can help transition from linear to a circular economy, either separately or combined.

Table 1. ReSOLVE framework detailed overview.

\begin{tabular}{ll}
\hline Framework Element & Description \\
\hline Regenerate & $\begin{array}{l}\text { "REgenerate" action describes the aspiration to } \\
\text { restore the ecosystems, e.g., use renewable sources } \\
\text { of energy. }\end{array}$ \\
\hline "Share" action calls to prolong the lifetime periods \\
of the products through sharing them among \\
several users.
\end{tabular}

The conducted semi-structured survey questions cover the following sides of the circular economy (1) local awareness of circular economy; (2) use of organic, second-hand, or high-value recyclable construction materials; (3) tendency to use design for disassembly principles; (4) tendency to design multipurpose areas; (5) attempt to reduce the potential construction and demolition waste; and (6) use of building information modeling (BIM). Each of these questions differently assesses the value conservation of the building elements, as each of the corresponding ReSOLVE framework elements aims to increase their lifetime, improve their post-lifetime use and increase the level of digitalization. The questions and their alignment with the ReSOLVE framework elements are given in Appendix A.

\subsection{Data Analysis}

In the beginning, the construction trends in the country were analyzed. The analysis employs the PEST tool to define political, economic, social, and technological factors affecting the trends in the construction industry [18].

Next, barriers and opportunities to the circular economy in Kazakhstan are identified based on the interviews of stakeholders. These are classified by the type of construction activity that stakeholder performs (client, manufacturer, designer, or contractor) and also by the type of relation to the elements of the ReSOLVE framework.

As part of the assessment of potential barriers and opportunities, the numerical scores for each component of the ReSOLVE framework are calculated based on the average of the ratings given to survey participants' answers. The rating range for opportunities is $0-5$, where 0 is no opportunity for development, and 5 is an open opportunity with direct impact. On the other hand, ratings for barriers range from -5 to 0 , where -5 is a strong barrier that impacts the implementation of such a principle and 0 is no barrier. According to the cumulative average score from all stakeholders for each component of the framework, 
the order list could be constructed that provides a view for the order list in which each of the circular economy principles could be gradually applied to all stakeholders. This method is a quantitative part of the strategy of circularity application.

\section{Results}

\subsection{Overview of Kazakhstan Construction Sector}

As of May 2021, there are 52,096 different stakeholders involved in the construction sector in Kazakhstan, dealing with extraction of secondary materials, manufacturing of the primary materials, building and construction works, waste processing, and trade. Out of the total number of stakeholders- $43,486(84 \%)$ are involved directly in construction activities, with the majority $19,015(37 \%)$ in the development and construction of residential and nonresidential buildings. Only 1257 or (2\%) of companies specialize in collecting, treating, and disposal of waste [19]. The shares by the stakeholder types are represented in Figure 1. The total number of landfills across the country is 19,924, with 12,176 active landfills—out of which only $5 \%$ meet the required standards and $73 \%$ are unauthorized [20].

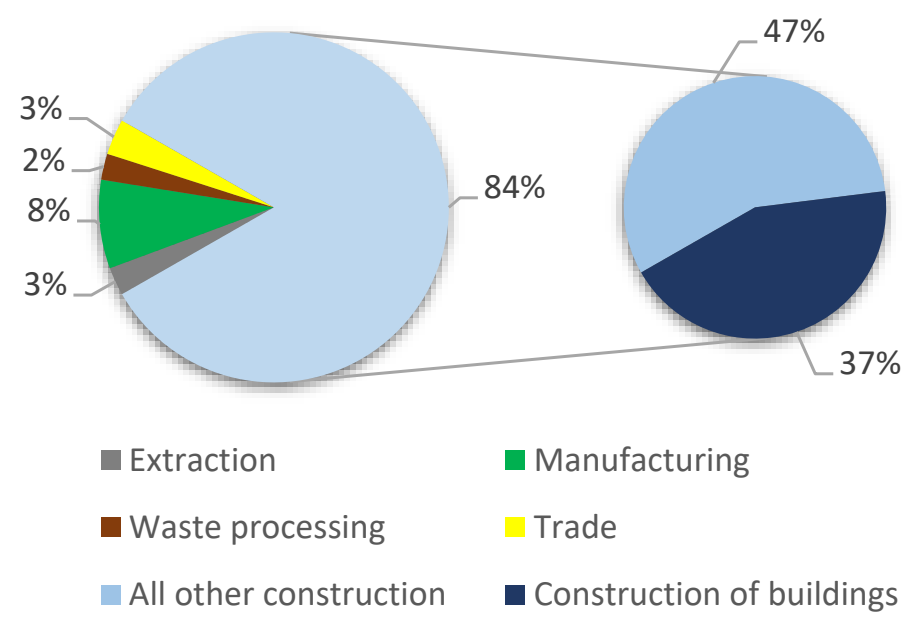

Figure 1. Shares of the stakeholder numbers in the construction sector of Kazakhstan by activity types.

Construction activities in the country include intermediate production and building/infrastructure construction activities-the intermediate materials needed for construction stages of buildings and infrastructures. The intermediate production phase mainly uses domestic raw materials coming from upstream processes of the value chain. Import rates are generally low, with the highest rate of prefabricated building metal structures $(9 \%)$. Table 2 summarizes the annual average of the consumption of intermediate materials in Kazakhstan's construction value chain and provides the proportion of imports of these materials.

Table 2. Intermediate production and import rates of the Kazakhstani construction sector (own elaboration based on [19]).

\begin{tabular}{ccc}
\hline Intermediate Material & Consumption & Import Rate (\%) \\
\hline Ready-mixed concrete & $20.2 \mathrm{Mt}$ & $0.0 \%$ \\
Concrete products for construction & $6.2 \mathrm{Mt}$ & $2.2 \%$ \\
purposes & $1.1 \mathrm{Mt}$ & $0.4 \%$ \\
Prefabricated concrete structures & $0.8 \mathrm{Mt}$ & $0.8 \%$ \\
Building solutions & $0.1 \mathrm{Mt}$ & $9.0 \%$ \\
Prefabricated building metal & $28.3 \mathrm{Mt}$ & \\
structures & &
\end{tabular}


The construction activities involve constructing residential buildings, nonresidential buildings, transportation infrastructure, water infrastructure, and other civil infrastructure. Table 3 summarizes the economic impact of construction activities in the country and their percent contribution to the total construction investment. The annual volume of expenditure on dismantling and demolition of buildings and structures was KZT 1.06 billion in 2015, and it increased KZT 1.6 billion in 2019.

Table 3. Economic values of construction activities (the average of 2015-2019) (own elaboration based on) [19].

\begin{tabular}{ccc}
\hline Construction & Billion Tenge & $\%$ \\
\hline Residential buildings & 392 & $12 \%$ \\
Non-residential buildings & 727 & $22 \%$ \\
Transportation infrastructure & 692 & $21 \%$ \\
Water infrastructure & 323 & $10 \%$ \\
Other civil infrastructure & 655 & $19 \%$ \\
Services for building construction & 574 & $17 \%$ \\
Total & 3363 & $100 \%$ \\
\hline
\end{tabular}

\subsection{Survey Results}

\subsubsection{The Level of CE Concept General Awareness in Kazakhstan}

Half of the respondents indicated that they are not aware of CE concepts and principles in construction (Question 1). The other half of respondents exhibited little to moderate knowledge and awareness of the CE applications in CE. Their area of expertise or practice is related to sustainable construction methods in some ways, and they have already applied relevant methodologies in practice. Depending on the company business, their applications vary, from applying lean principles in the production of materials by minimizing waste at the design stage to using prefabricated materials for client companies. To some extent, almost every company attempts to exploit approaches that suit a part of the ReSOLVE framework and hence, exploit circular economy principles in practice. If appropriately introduced and supported, this result indicates the highest adoption potential of the CE principles in the Kazakhstani construction sector.

\subsubsection{Construction Materials}

Several companies $(80 \%)$ answered (e.g., Questions II. 1, 2, 4) that it is hardly possible to use organic, refurbished, recyclable, environmentally friendly materials in practice. However, at the same time, some companies (50\%) stated some possible motivation that could push them to start applying this principle in practice. The main objective of construction materials selection is quality-cost effectiveness. The designers and contractors did not generally consider the criteria such as organic content, eco-friendliness, recyclability, and recycled content. Only one respondent identified eco-friendliness and organic content as the prevailing factor in selecting materials in their projects, addressing the availability of such type in the local market. Nevertheless, such materials are more expensive and/or labor-intensive to install than the non-organic or less eco-friendly alternatives in almost every case in the selected country context.

More than a quarter of the respondents (28\%) stated that up to $25 \%$ of organic-based materials were used during construction, and the rest reported considerably less. The organic-based materials, which are economically feasible and used significantly, are wooden materials (e.g., accessories for internal finishing, exterior landscape, roofing frame, door frames), drywall, shell limestone blocks, and natural stones (e.g., used for external cladding such as granite). Respondents stated that using organic materials in significant amounts is challenging because other materials have already proven their quality, and their replacement could be problematic in terms of market and sector trends. Additionally, more than half of respondents answered that no available market-ready solution could be implemented in practice. However, there is an opportunity existing for pushing companies 
to employ such principles. Several big companies stated that the application of organic materials could occur if specific legislative regulations would happen. There should be positive motivations and incentives to use circular materials in the sector from both government and all other actors of the construction ecosystem. The use of organic content in construction projects used to be higher during the Soviet period, as recalled by two respondents that have been in business for long enough that they witnessed that period. It included products to a significant extent from agricultural waste, unvulcanized natural rubber, and natural clay, and, nowadays, they are being replaced mainly by petrochemical products (e.g., from timber window frames to PVC ones).

Less than $10 \%$ of the respondents reported using reused/ refurbished materials in their projects, including precast parts from reinforced concrete such as slabs. It is mentioned that all the materials are brand new. The nonexistence of the infrastructure for materials refurbishment and the unavailability of readily available refurbished products are identified as the participants' barriers that support their decisions. Additionally, companies mentioned that it is problematic to utilize used or old materials for the new construction as parts could be different. In addition, designers always prefer to select construction parts and components to be new at the design stage. There is no available database, platform, or market of used materials that could be exploited for a new project. It was also stated that every construction project is unique due to business type, and it is difficult to search for used parts to be implemented. Additionally, the stakeholders from the largest companies in the sector mentioned that it could be a bad reputation to use old materials. Talking about the opportunities identified regarding refurbished materials, almost every company mentioned that it is possible to use such if the properties of such materials are certified and comparable to the new ones. Even the economic point of view can be used as an advantage to promote them. One respondent who specialized in public infrastructure projects stated that due to their activities being strictly regulated by current legislative norms, reused, secondary, and refurbished materials cannot be used in their practice. Additionally, one company stated that if the market price for new materials increases, it would direct the users to secondary materials, but properties should be satisfactory.

Most of the companies dealing with residential construction mentioned that more than half of the projects usually consist of recyclable materials such as concrete, reinforcement steel, gas block, drywall, chipboard, and plywood. Some companies that do not deal with concrete works said it is challenging to use recyclable materials because of the exploitation of the business and materials. The majority of companies did not mention any new opportunities and barriers in this question. Other companies stated that proper and wellpracticed solutions should exist to be applied in their domain. The most potent recycled materials identified based on their current utilization are asphalt, concrete, sheeting rubber plates, wallpaper, and styrofoam blocks.

It was revealed that the main criterion for materials selection is cost-quality benefit. Respondents stated that their choice falls on the least expensive materials that meet the functional and quality requirements. Larger-sized companies with procurement departments have well-established procurement procedures, long-term relations with suppliers, and continuously monitor market prices. In almost all cases, companies do not have information of the origin of the constituents of the materials-many materials that have high recyclability potential, e.g., drywall products and ready dry mixes, do not specify their recyclable content. Further, respondents provided that they are not aware of the local manufacturers or suppliers that offer such a selection, and that these types of materials are not promoted or marketed.

\subsubsection{Design for Disassembly}

The interviews have demonstrated that Design for Disassembly (DfD) and associated building methods are not common among parties involved in construction. Whenever those are preferred, it is usually dictated with financial profit perspectives rather than a commitment to the circular economy. Only one company has answered that they are 
interested in DfD and attempt to implement it when possible, but this choice is also associated with further economic savings that DfD can offer. Talking about choosing dry (which are preferred in DfD) or wet (which complicated further building disassembly) building methods, only two companies implement dry methods, while others prefer those techniques which are more efficient at the construction process, i.e., cheaper or require less time. No stakeholder has responded positively about using structures able to disassemble in the design of their building. Those are used only for temporary structures in industrial sites and field offices/dormitories. Talking about adaptation or refurbishment of the existing structures instead of its demolition, this approach is used only regarding built heritage, as legislation requires. In addition, the interview results have demonstrated that stakeholders expect that pursuing DfD methods should become a shared concern between all the involved parties - clients, designers, architects, and builders. Otherwise, builders follow technical maps prepared by architects, which are not interested in the buildings ${ }^{\prime}$ life-cycle after completing their design. Overall, DfD has a prospect for development in the Kazakhstani construction sector when shown a certain economic profit, defined in legislative regulations, and shared responsibility and interest of all the construction parties.

\subsubsection{Buildings Multifunctionality}

Regarding the sharing part of the ReSOLVE framework, the multifunctional areas are addressed as priority CE actions in the construction sector. The respondents stated that designing multipurpose and shared areas is not common in their practice in Kazakhstan. Instead, the current situation is more related to maximizing the floor space to maximize the commercial benefits. One of the companies dealing with industrial building construction stated that they consider multipurpose areas, but proper expertise should be performed at the design stage. Additionally, one more company supported the idea that if a project is not the residential type for selling but an industrial building, it is possible to apply such principles, and proper communication between client and contractor should happen. It is found that this principle is employed only on rare occasions; for instance, at a hotel project, its largest banquette hall was designed with several mobile partitions that are designed to transform the hall into smaller separate conference halls that allow simultaneous use of them. At the same project, the designers have left a few rooms with standard utilities and minimal finishing with no specific designation that can be used per final occupant needs, assuming their purpose can change over time. The most common barrier was added as the monetary benefits. Another barrier was, again, the current pricing policies for construction materials. If the material and construction costs were lower, it could save the margin and provide a multifunctional area for clients. As an opportunity, one company mentioned that governmental regulation could influence the position of residential construction companies to use such CE principles massively.

\subsubsection{Construction and Demolition Waste Minimization}

All of the respondents stated that reducing the potential waste of construction materials is always considered, and materials leftovers are stored for further usage-which is dictated by economic reasons. Two respondents mentioned that they follow lean principles in order to minimize waste. However, unfortunately, all of the generated waste ends up entirely in designated dumping areas. Currently, this practice does not comprise high costs to handle waste in such a way, and mostly no rules and guidelines are set in project documentation related to waste management. Some companies practice waste segregation more than others, even though this segregated waste follows the same routine (no circularity with practices to close the loop). Only one company stated that their waste is mainly from earthwork and demolition of structures, roads, and pavements; they transport their waste into designated storage areas and then this waste is reused for the city's new actively growing areas for backfilling (e.g., compaction of the foundation works, or to elevate the existing ground levels). Another company practices sorting the steel and other metal parts and handling them to specialized companies for further recycling. One reported 
that they use industrial waste, e.g., fly ash, as an additive for the concrete since they are self-motivated by the quality features. As an opportunity, companies stated that good management on construction sites is the key factor in reducing waste. The contractors' poor performances and lack of proper infrastructure and facilities are the main barriers to better C\&D waste management compliance with CE principles.

\subsubsection{BIM}

Building Information Modeling has good adaption across the respondents-More than half of them responded (\#10) are actively employing BIM (e.g., BIM 360, ArchiCAD, AutoCAD, Revit, and others). Only smaller enterprises are yet to employ such technology, or due to their scale and/or business type, they stated that they do not require it. They stated that they immediately identified major construction faults and interdisciplinary clashes during the preconstruction period, potentially reducing reworks on-site, and one respondent used BIM to model and optimize the utilities and overall energy consumption of the projects. Further, BIM is used to revise the material quantities, identify quantity estimate errors, and take appropriate action to not delay the construction process due to material shortages. BIM is considered to have great potential in the Kazakh construction sector for providing circularity.

\subsubsection{Barriers and Opportunities out of ReSOLVE Scope}

It is essential to include the barriers and opportunities respondents mentioned out of the nine main questions (ReSOLVE oriented). These barriers include a high level of unawareness in circularity principles among citizens and a low-level self-consciousness in reducing the over-consumption of goods, energy, and water. The individual actions for waste minimization, segregation, and recycling affect the circularity in general across the industry. Next, some outdated construction standards have not been changed for decades, are still applicable, and often cannot open room for new construction methods, world best practices, and more sustainable and circular technologies. Last, the lack of qualified personnel with CE expertise is immense.

Adapting the current legislation to the new challenges and stricken its implementation, e.g., enforce the control and increase the penalty fines, is among the potential opportunities suggested. Another one is the improvement of the maintenance services for multistory residential buildings - this maintenance is often poorly managed, especially for old sovietera buildings. According to the current legislation, the residential building complex is communal property belonging to the apartment owners (in equal shares) who must collectively make decisions and set fees for maintenance and hire service companies. This system created a "no individual responsibility" situation that results in reactive maintenance rather than preventive; proper maintenance of these properties would significantly prolong their service life and improve their condition.

\section{Discussion and Implications}

\subsection{Construction Trends in Kazakhstan}

The current situation of the construction industry in Kazakhstan is assessed from various perspectives; these include the political, economic, social, and technological factors that shape and influence the industry. The results are aggregated with the PEST framework mapped in Table 4. 
Table 4. PEST analysis of construction trends in Kazakhstan.

\begin{tabular}{ll}
\hline Political Factor & $\begin{array}{l}\text { Financial support for the real estate development } \\
\text { Strategy to develop renewable and alternative energy sources, reduce } \\
\text { energy costs and CO2 emissions }\end{array}$ \\
\hline \multirow{3}{*}{ Economic Factor } & $\begin{array}{l}\text { Construction is one of the leading economic industries } \\
\text { The consistent growth of the construction capacities } \\
\text { Increasing production rate of construction materials } \\
\text { The steady increase of the construction materials prices }\end{array}$ \\
\hline \multirow{3}{*}{ Social Factor } & Urbanization process \\
& $\begin{array}{l}\text { Residential construction growth } \\
\text { Lack of qualified personnel }\end{array}$ \\
\hline & Digitalization (blockchain, smart home, BIM) \\
Technological Factor & $\begin{array}{l}\text { Modular construction } \\
\text { Recycling mining waste and sub-products }\end{array}$ \\
\hline
\end{tabular}

Political influence: Residential construction is a major activity in the construction sector, showing growth and consistent demand since the beginning of the 21st century. Kazakhstan has been supporting both contractors and citizens financially to promote and boost the local economic activity in the real estate sector. New mortgage programs are introduced continuously through various state bodies. These programs such as "Nurly Zher," "2-10-20", “5-10-20", "5-20-25", "7-20-25", "Baspana Hit," and others are intended to capture all levels of income households aiming to improve their living conditions [21]. At the same time, as part of the state development global strategy "Kazakhstan 2050", Kazakhstan is striving to produce up to $50 \%$ of energy from alternative and renewable energy sources along with reduction on energy costs, provide entire population and agricultural sector with clean water and reduce $\mathrm{CO}_{2}$ emissions into the environment [22].

Economic influence: The construction industry in Kazakhstan is one of the core industries that is meant to create appropriate conditions for the whole economic development of the country. The construction sector constitutes about $5.5 \%$ of the republic's GDP, making it the fifth-largest contributing sector to the gross product value [23]. The amount of construction works from January to March 2021 constituted 1.2B USD in monetary and 2.867 M square meters; in comparison, these indicators were $13.1 \%$ lower during the same period last year [24]. Even though the COVID pandemic caused the reduction of economic activities and cost reduction in businesses, the construction industry in Kazakhstan showed a growth of 11.2 percent, contributed mainly by residential construction [10]. Local production of construction materials constitutes about $6 \%$ of the total production industry. The production of steel reinforcement, masonry, cement, construction blends, thermal insulation, and drywall is projected to be increased in the range of $11-16 \%$ by the end of 2021 [25]. In addition to that, since the beginning of 2020, a rapid increase in construction materials cost was observed-concrete by $12 \%$, cement by $5 \%$, polyethylene pipes by $10 \%$, masonry blocks by $6 \%$ with the highest increase in steel prices by more than $45 \%$ [25].

Social influence: Urbanization is a global trend across developing countries and boosts the demand for residential infrastructure. Today the average residential floor space per capita in the country is around 21.9 square meters, whereas the UN sets the standard to be around 30 square meters [26], and most of the developed countries are far exceeding this standard (e.g., Denmark, Netherlands, Germany and USA with 77, 56, 53 and 74 square meters per capita respectively) $[27,28]$. As a developing country, Kazakhstan has much capacity to improve and develop by sustaining the social dimension of its population. According to the vision of the largest private construction companies in Kazakhstan for the next ten years, it is expected to have (1) further increase in residential construction as a result of rapid urbanization, (2) development of the manufacturing industry on "smart" cities and houses, (3) and more development of public infrastructure projects (e.g., gasification of the regions) [29]. The Kazakhstan Construction workers' union states that the construction industry is experiencing a shortage of young and talented construction 
workers specifically for blue-collar trades. Today youngsters do not have any incentives to go to construction sites, as the construction industry is perceived as outdated and old. The union chairman sees a potential to seek labor force from neighboring countries, but they are also experiencing similar demographic trends [30]. However, a research team from the "Atlas of new professions and competencies of Kazakhstan" believes that Industry 4.0 will inevitably vanish the "outdated" traditional construction trades and displace them with new trades. They will be related to BIM technologies, AI, robotization and automation, modular construction, 3D printing, and other "green" technologies [23].

Technological influence: Historically, the role of the government in construction activities across the country has been enormous. To enhance the transparency of construction processes, reduce paperwork and take control over the quality, the unified information system was developed and employed by all stakeholders involved in the construction business when it is related to the state orders. This information system called "E-Kurylys" is a blockchain-based technology that eliminates third-party interference and promotes transparency across all levels [10]. This system was developed by the state and included in the current legislation. It covers all stages of the construction process in all regions of Kazakhstan, providing access to technical documentation. In addition, this unified system will provide access to fire safety, sanitary, epidemiological, and other interested authorities to implement safety control. The introduction of the "E-Kurylys" system allows (1) supervising digital technical reports, (2) identifying nonconformities with the construction requirement, and controlling construction deadlines by significantly reducing paperwork. Future works within the "E-Kurylys" system to improve state control and reinforcement of construction requirements include integrating construction regulations and normative documents. All contractors must use this feature; however, local industry experts doubt this will significantly improve the situation [23]. Nevertheless, this item is employed and is expected to improve while the whole construction ecosystem improves.

Smart technologies have already found their way to Kazakhstan consumers. Smart home features coupled with the internet of things technology significantly reduce and optimize the utilities (water/heat/electricity) and energy (gas) use of the household, as well as eliminate or minimize the effects of the potential emergency failures that can occur within the household, e.g., gas leak, water pipe burst or faucet failure [31].

Kazakh Research and Design Institute of Construction and Architecture is looking optimistically towards BIM technology. BIM has allowed achieving more accurate quantity estimates by $3 \%$, shortening the time consumed for quantities estimates by $80 \%$, and shortening the overall project duration by $7 \%$. BIM technologies are also proven to be one of the most common and effective tools in reducing construction and demolition waste by improving the planning/scheduling activities and spotting the design errors at the design or planning stage, thus reducing reworks [11]. With these promising numbers, the Ministry for Investment and Development of the Republic of Kazakhstan has set an action plan to implement BIM technology in the design and construction of state facilities [32].

One of the largest local companies in the construction sector puts special belief in modular construction for residential needs. The company has already set up a factory producing building modules and has accomplished a few pilot projects. The company's vision is to build residential units within a shorter timeframe and employ less workforce than the traditional construction methods [29]. Moreover, beyond the economic benefits, modular construction has additional benefits compared to traditional construction methods in the region (e.g., use of eco-friendly materials and expanded clay concrete; better noise and heat isolation; better quality and precision, minimization of errors of the final building because of in-shop prefabrication of building blocks which are often produced on the robotized equipment) [33].

A Kazakhstani multinational mining and natural resources company has taken big steps towards reducing its carbon footprint by minimizing and recycling the mining waste and sub-products and turning them into construction materials [34]. However, in the research conducted by Turkyilmaz et al., it is suggested that within the current economic 
situation in the country, construction waste recycling has a lower potential to contribute to waste reduction than reduce and reuse approaches [9]. It may be seen as primarily suitable for the construction industry, as for the mining company-that turning what would be considered a waste and stockpiled-into secondary materials that often have price advantage without compromising quality.

\subsection{Barriers and Opportunities to $C E$}

Based on the stakeholder interviews, the barrier and opportunities matrix is constructed in terms of the ReSOLVE framework (Figure 2). This matrix covers four stakeholder types-clients, contractors, designers, and manufacturers that constitute the construction ecosystem. The missing points in the matrix are because such points did not apply to the business scope of stakeholders and could not be addressed.

\begin{tabular}{|c|c|c|c|c|c|}
\hline & Client & Contractor & Manufacturer & Designer & \\
\hline \multirow{4}{*}{$\begin{array}{l}\text { Regen- } \\
\text { erate }\end{array}$} & $\begin{array}{l}\text { Use of second-hand } \\
\text { materials are not desired }\end{array}$ & \multicolumn{2}{|c|}{$\begin{array}{l}\text { Non-organic materials have better characteristics and } \\
\text { quality than biodegradable ones (high-quality organics } \\
\text { are not available) }\end{array}$} & $\begin{array}{l}\text { No reuse principles are ex- } \\
\text { ploited }\end{array}$ & Barriers \\
\hline & \multicolumn{3}{|c|}{ The price advantage of the non-organic, less eco-friendly materials } & & \\
\hline & $\begin{array}{l}\text { Legal regulations could push to } \\
\text { use more eco-materials }\end{array}$ & $\begin{array}{l}\text { Actively use Eco ma- } \\
\text { terials as instruments }\end{array}$ & $\begin{array}{l}\text { Use more structures that em- } \\
\text { ploy high recovery materials } \\
\text { (e.g., steel and wood) }\end{array}$ & $\begin{array}{l}\text { Plan renovation at the de- } \\
\text { sign stage }\end{array}$ & $\begin{array}{l}\text { Opportu- } \\
\text { nities }\end{array}$ \\
\hline & \multicolumn{2}{|c|}{$\begin{array}{l}\text { Explore the local suppliers and manufacturers of recycled } \\
\text { / organic / bio-based materials } \\
\text { Explore organic-based materials available in the vicinity }\end{array}$} & & & \\
\hline \multirow[b]{2}{*}{ Share } & $\begin{array}{l}\text { Multipurpose areas are not fi- } \\
\text { nancially beneficial }\end{array}$ & $\begin{array}{l}\text { No orders from the } \\
\text { client }\end{array}$ & $\begin{array}{l}\text { Project uniqueness does not } \\
\text { allow to share materials }\end{array}$ & No orders from the client & Barriers \\
\hline & $\begin{array}{l}\text { Search for the possibility to per- } \\
\text { form renovations with the least } \\
\text { amount of new materials }\end{array}$ & \multicolumn{2}{|c|}{ Instruments are shared through the projects } & $\begin{array}{l}\text { Provide recommendations } \\
\text { for the client in terms of } \\
\text { multifunctionality }\end{array}$ & $\begin{array}{l}\text { Opportu- } \\
\text { nities }\end{array}$ \\
\hline \multirow{2}{*}{$\begin{array}{l}\text { Opti- } \\
\text { mize }\end{array}$} & & & & $\begin{array}{l}\text { Not available database of } \\
\text { materials to optimize de- } \\
\text { sign solution }\end{array}$ & Barriers \\
\hline & $\begin{array}{l}\text { Use of modular technologies } \\
\text { Provide service management af- } \\
\text { ter project execution }\end{array}$ & $\begin{array}{l}\text { Avoid wet methods } \\
\text { by using mechanical } \\
\text { connections }\end{array}$ & $\begin{array}{l}\text { Production optimization in } \\
\text { the future by automation }\end{array}$ & $\begin{array}{l}\text { Avoid complex design solu- } \\
\text { tions }\end{array}$ & $\begin{array}{l}\text { Opportu- } \\
\text { nities }\end{array}$ \\
\hline \multirow{3}{*}{ Loop } & No recyclable infrastructure & $\begin{array}{c}\text { Non-controllable } \\
\text { waste management }\end{array}$ & No recyclable infrastructure & $\begin{array}{l}\text { Not available database of } \\
\text { materials to use in a loop } \\
\text { design solution }\end{array}$ & Barriers \\
\hline & Ask for materials passports & Perform waste audits & $\begin{array}{l}\text { Provide a guarantee for pro- } \\
\text { duced materials } \\
\text { Recycle materials with high } \\
\text { recyclability potential }\end{array}$ & $\begin{array}{l}\text { Try to apply standard } \\
\text { shapes so some materials } \\
\text { could be repeatedly used }\end{array}$ & $\begin{array}{l}\text { Opportu- } \\
\text { nities }\end{array}$ \\
\hline & \multicolumn{2}{|c|}{ Reuse C-DW for backfilling works } & & & \\
\hline \multirow[t]{2}{*}{$\begin{array}{l}\text { Virtual- } \\
\text { ize }\end{array}$} & & $\begin{array}{c}\text { Visual technologies } \\
\text { are not always re- } \\
\text { quired }\end{array}$ & & & Barriers \\
\hline & High pace BIM development & $\begin{array}{l}\text { Young professionals } \\
\text { actively develop BIM } \\
\text { usage }\end{array}$ & \multicolumn{2}{|c|}{ Active BIM usage } & $\begin{array}{l}\text { Opportu- } \\
\text { nities }\end{array}$ \\
\hline \multirow{3}{*}{$\begin{array}{l}\text { Ex- } \\
\text { change }\end{array}$} & \multicolumn{3}{|c|}{$\begin{array}{l}\text { Cost of implementation } \\
\text { o check new technology to implement in projects }\end{array}$} & \multicolumn{2}{|r|}{ Barriers } \\
\hline & $\begin{array}{l}\text { Use advanced technologies (e.g., } \\
\text { building blocks, drones) }\end{array}$ & $\begin{array}{l}\text { Search for newly de- } \\
\text { veloped technologies } \\
\text { on the market }\end{array}$ & $\begin{array}{l}\text { Use advanced technologies } \\
\text { (e.g., building blocks, drones) }\end{array}$ & $\begin{array}{l}\text { Use design for deconstruc- } \\
\text { tion method }\end{array}$ & $\begin{array}{l}\text { Opportu- } \\
\text { nities }\end{array}$ \\
\hline & \multicolumn{3}{|c|}{$\begin{array}{l}\text { on the market } \\
\text { Include industrial waste for primary materials production, e.g., fly ash }\end{array}$} & & \\
\hline
\end{tabular}

Figure 2. Stakeholder barriers and opportunities analysis in the ReSOLVE framework. 
The local awareness level of CE principles is generally in line with the global level, although the understanding of CE implementation in construction is deficient across the world compared to the other industries [3]. Respondents put special attention on cultural awareness, and individual self-consciousness of reducing carbon footprint-cultural behavior and individual understanding of how unsustainable methods affect climate change are the key factors in the circular economy model globally $[35,36]$. Other researchers also accept the financial issues as the main obstacle to the more circular model and stress on the leadership idea as a "facilitator" for circularity shift, as the construction industry is mostly very conservative, uncooperative, and risk-averse [36,37]. Tingley et al. (2017) address the government's step into the leadership role and kick start the industry [38].

Local stakeholders are not incentivized to apply DfD concepts-with main barriers being reported as economic reasons, in contrast with barriers described in the EU contextthose included lack of legislation for deconstructed facilities, lack of related information at the design stage, not standardized salvaged materials in addition to the cost burden [38-40]. However, the findings supported that stronger interdisciplinary collaboration between stakeholders and supply chain levels is critical [35,37]. These barriers may seem to be the next challenges after financial, in circularity route for the developing countries.

In terms of the material flow, the survey identified common barriers described by Debacker et al. (2016) — the lack of specifications, properties and conditions for reused products, quality concerns, and limited suppliers. The authors suggest to establish countrywide urban mining concept and bring the new players into the industry that will be secondary material producers with appropriate design profile; and innovative business model within the market context such as "pay-by-use" and "product as the service," leaving ownership of the materials to the supplier [41]. It is also fair to note that the secondary materials do not have a mature market globally in the construction value chain, and implementing the CE principles into the business model is not obvious at the current stage $[40,42]$.

\subsection{Policy Recommendations}

Based on the obtained survey results, the numerical evaluation of the potential implementation extent was derived. Ratings of opportunities and barriers were given to the participants' answers. For each component of the ReSOLVE framework, the numerical score was calculated to construct the policy list that provided an order in which circular economy implementation could be integrated into the construction ecosystem. According to the constructed chart shown in Figure 3, most opportunities are about "virtualize" and "loop" components. However, the "loop" part has a lower rating in terms of barriers; therefore, virtualization is the first priority for developing a circular economy in the construction sector. Then there is the "exchange" component has fewer opportunities and less score for barriers than the "loop" part, which is the third. Based on the scores, the bottom three are optimize, regenerate and share options. That analysis could be interpreted as a strategy the construction sector should follow to gradually implement each component step by step to achieve a higher level of circular economy, which in its turn should reduce the amount of waste and provide a monetary benefit to the economic part.

Firstly, in terms of "virtualization," the majority of participants of the ecosystem stated that BIM technologies are already in use, and there is continuous development in this area. There are limited barriers that contribute to the readiness of companies to create this crucial component part of these businesses openly. There should be a condition where BIM technologies are broadly integrated into all the components of the construction ecosystem, for instance, material passports to be integrated into BIM, which will allow users to keep track of materials, their origin, and quality [42,43]. This implementation would improve the quality of planning and design, which could reduce expenses on the procurement and the amount of force needed. In addition, BIM should be included in the construction supply chain system for waste minimization purposes [44]. 


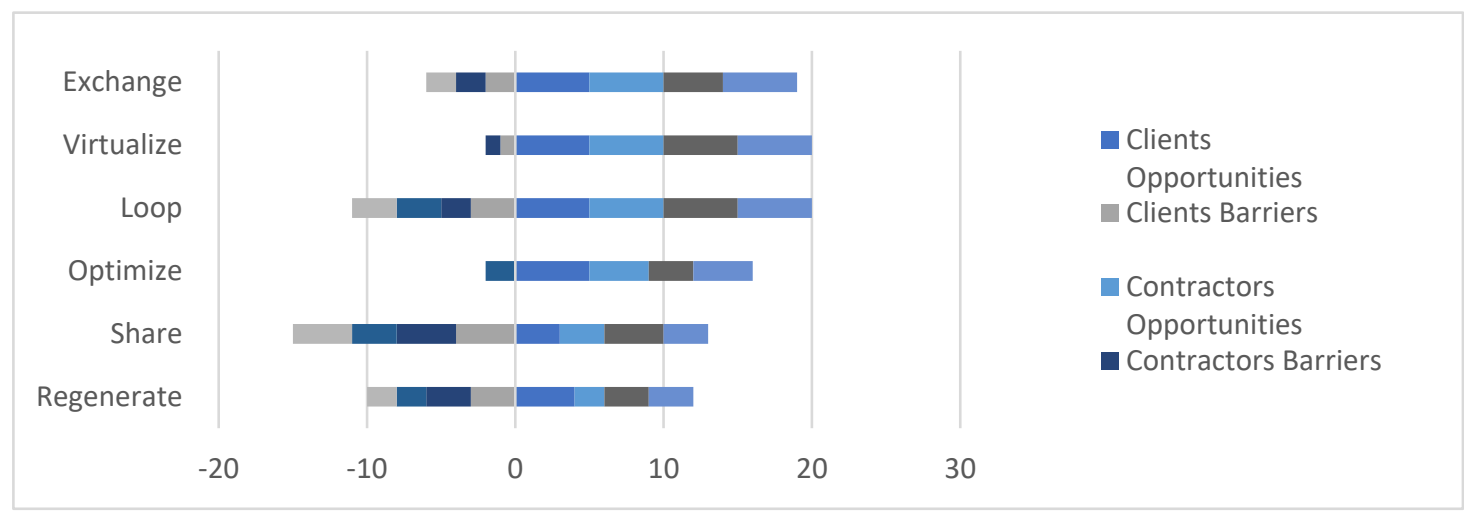

Figure 3. Barriers and opportunities score based assessment in terms of ReSOLVE framework.

Secondly, covering the "exchange" component, all the participants mentioned their readiness to apply new technologies such as drones, 3D printing, design for disassembly methods to bring innovativeness to the construction process. However, almost every party stated that there are monetary barriers that could restrict the application of these. Therefore, technology companies could support technology to implement new high-tech products in practice and produce a profitable cross-business. One potential opportunity can be design for adaptability, the concept considers how the building can be simply converted for other uses and readapted with minimal internal distortion; this concept is more uncomplicated than the DfD approach [41,45].

Regarding the "loop" component, the clients and manufacturers addressed no infrastructure to recycle materials. Additionally, designers stated that there is no database for appropriate materials from other projects for new designs. Misconceptions regarding reused and recycled materials are taking place too, which is not surprising as identified in other research works [43]. Mahpour et al. (2018) propose replacing recycling C\&DW with upcycling to produce high-quality materials and overcome this misconception [37]. That way, parties are ready to consider looping some materials if it benefits the project. Additionally, the need for infrastructure could be fulfilled by developing technologies in this area or could be brought by the governmental initiative. So, circularity in this term would be applied.

Talking about "optimization," almost every stakeholder identified specific opportunities that potentially could be implemented, but these are limited, and it is difficult to perform continuous optimization without the usage of additional support from other parties and newly available technologies. Such technologies will eventually be introduced, such as off-site industrialization that is gaining more popularity in the EU context, and if properly managed, can reduce construction costs significantly [42,45].

Regarding the "regenerate" option of the framework, it is not easy to use more organic materials because of their inferior properties or higher cost of implementation compared to composite non-organic materials. However, several respondents undoubtedly consider this if a governmental regulation favors an increasing percentage of organics in construction projects. So, this could be a push that brings circular economy principles into action. The use of non-organic materials with further disposal, landfilling, and incineration do not fit the circularity model, and recycling or upcycling methods should be employed at the end of the life cycle [37]. It is also advised for stakeholders to explore organic-based materials available in their vicinities that will meet the quality properties at a competitive price; the example can be shell limestone blocks available in the Mangystau region and actively used there. Although the misconception regarding the quality of organic-based materials also exists, which is partially justifiable, still numerous natural materials that are both sustainable and have high performance do exist, including organic wool, flax fiber, earth-based blocks [45,46]. 
The last part of the list is "share." This option suggests sharing resources (e.g., machinery, equipment, huge vehicles) among the stakeholders. Internal sharing practices positively affect economic, environmental, and social performance, while external positively affects environmental performance [47]. Regarding creating shared space and multipurpose areas within the buildings- the contractors and designers answered that this initiative should go from the client part. Therefore, to pursue the "share" principle, client companies should consider it as an addition to the projects. This option can also be achieved by including the PSS (product-service system) business model, which combines the provision of both products and services. However, the major argument against the "share" principle inclusion into the business models is a monetary issue with several external factors such as currency volatility and external politics. COVID-19 pandemic is an example that played a crucial role in company management decision-making regarding budget controlling and attempts to profit generation.

In addition, the interviews with the stakeholders from the construction sector resulted in the project proposal ideas collection, which is summarized in Figure 4.

\begin{tabular}{|c|c|c|c|c|}
\hline $\begin{array}{l}\text { Use more prefab } \\
\text { materials, organic, } \\
\text { renewable materials, } \\
\text { environmentally } \\
\text { friendly, DfD }\end{array}$ & $\begin{array}{l}\text { New and robust } \\
\text { regulations regarding } \\
\text { construction } \\
\text { standards }\end{array}$ & $\begin{array}{l}\text { Future renovation } \\
\text { works to prolong } \\
\text { building life }\end{array}$ & $\begin{array}{l}\text { Affordable and } \\
\text { compatative prices } \\
\text { for the materials }\end{array}$ & $\begin{array}{l}\text { Use advanced } \\
\text { technologies and } \\
\text { new constrcution } \\
\text { methods/inovation }\end{array}$ \\
\hline $\begin{array}{l}\text { Provide easy access } \\
\text { to pipes and tubes for } \\
\text { deconstruction }\end{array}$ & $\begin{array}{l}\text { Use more light } \\
\text { materials }\end{array}$ & $\begin{array}{l}\text { Apply lean principles } \\
\text { to reduce waste }\end{array}$ & $\begin{array}{l}\text { Increase the use } \\
\text { natural wood-based } \\
\text { materials for interior } \\
\text { finishing }\end{array}$ & $\begin{array}{l}\text { Develop in modular } \\
\text { construction in } \\
\text { private housing } \\
\text { sector }\end{array}$ \\
\hline $\begin{array}{l}\text { Replace some wet } \\
\text { processes with dry } \\
\text { e.g., screed with } \\
\text { concrete sheeting }\end{array}$ & $\begin{array}{l}\text { Restoration and } \\
\text { retrofit of historical } \\
\text { buildings in Almaty }\end{array}$ & $\begin{array}{c}\text { Improve } \\
\text { requirements for } \\
\text { maintenance services } \\
\text { of buildings }\end{array}$ & $\begin{array}{l}\text { Raise the citizen } \\
\text { awareness and } \\
\text { improve the } \\
\text { mentality towards }\end{array}$ & $\begin{array}{l}\text { Develop using BIM } \\
\text { for quantities } \\
\text { estimations }\end{array}$ \\
\hline $\begin{array}{c}\text { Change people } \\
\text { perception towards } \\
\text { waste generation and } \\
\text { waste handling }\end{array}$ & $\begin{array}{l}\text { Use industrial waste } \\
\text { for construction } \\
\text { materials as additives } \\
\text { e.g., fly ash and slag }\end{array}$ & $\begin{array}{l}\text { New local markets } \\
\text { for natural, organic, } \\
\text { recycled, eco- } \\
\text { friendly materials }\end{array}$ & $\begin{array}{l}\text { Reuse construction } \\
\text { waste as filler for } \\
\text { foundation }\end{array}$ & $\begin{array}{l}\text { Use recycled } \\
\text { aggregates for } \\
\text { concrete }\end{array}$ \\
\hline
\end{tabular}

Figure 4. Project proposals from Kazakhstani construction sector stakeholders.

\section{Conclusions}

Kazakhstan construction sector's stakeholders have substantial potential to continue (or, in some instances, to start) implementation of the CE principles into their practices. The construction sector has a considerable share within the country's economy, expecting to grow shortly, backed by certain social, demographic, economic, and political trends.

Talking about theoretical and practical implications, research conducted analyzed the current situation in the country in terms of the development of a circular economy and identified certain barriers and opportunities for the local stakeholders involved in the construction ecosystem. The main finding is the economic barrier because companies mainly could not afford risks that influence the profit. In the case of a circular economy, companies save construction materials for reuse or refuse rather than take a risk and use more eco-friendly technologies. Based on the barriers and opportunities assessment, the stakeholders' general recommendations were established to develop circular economy principles in practice further. Recommendations were provided based on the current state of companies and prioritized accordingly. These recommendations include continuous development of BIM technologies to improve project quality and economy at the design stage, prefer restoration rather than demolition, use more prefabricated materials in order to reduce the time for completing processes, attempt to exploit lean principles at a construction site to minimize waste, create infrastructure to open opportunity for recycling, share 
materials at the site rather than search for new ones. By considering such implications, government and local companies could benefit in terms of economy, environmental effect, and sustainability. In addition, several survey participants showed some interest in the ideas generation for the new projects that could develop circularity in the sector. This result presents the readiness of stakeholders to apply such methods and improve business by optimizing resource efficiency using circular economy principles.

The government positively affects the industry through financial programs and national strategies implementation. Yet, some essential CE principles should be initiated at the national level according to the stakeholders' opinions-although applying them may not be economically viable from the contractors' perspective. These include developing the CE-compliant waste processing facilities and adjusting the current construction and environmental legislation to address the new challenges. Private stakeholders also have the leverage to set up and enhance the CE implementation at their levels. These are partially abstracted from established material selection habits and traditional construction methods, starting exploration of alternative materials out of the organic-based, recycled content, and industrial waste. This area is underexplored compared to the successful CE practices implemented in Europe. CE-friendly materials are certainly present within the country but underestimated or labeled as low quality, and their market is at a small scale.

Established "non-circular" practices partially stemmed from another barrier-lack of qualified and aware personnel with CE expertise and current economic context within the free market, where players strive for cost optimization in order to sustain. Thus, applications such as BIM technologies found their respectable place since they provided economic benefit.

Applying CE principles to the construction sector is challenging enough and requires creativity in the Central Asian context. Every stakeholder can start implementation and experimentation with CE practices at their micro levels; however, significant and systematic results can be achieved collectively with the input of all stakeholders and governmental bodies.

In terms of the limitations of this study, some points should be mentioned. There was a limited number of available stakeholders to conduct a survey, but most responses play a crucial role in the current construction sector. Another weakness is the inability of respondents of private companies to share elaborated internal data. Therefore, there could be more detail yet with only general information obtained.

Referring to the future work of this research, there could be more information gained regarding circular economy actions from the stakeholders from other regions in order to improve the shortcomings of the current research. After complex policy establishment, there could be a study for strategy implementation inside the companies and government. Future studies could be based on the technical and economic analysis that provides a feasible solution to the stakeholders. Therefore, there could be proper conditions for the internal parties involved in the construction ecosystem in the country.

Author Contributions: Conceptualization, F.K., A.T. (Ali Turkyilmaz) and M.M.; methodology, B.T., A.Z. and A.T. (Aidana Tleuken); investigation, B.T. and A.Z.; writing-original draft preparation, B.T., A.Z. and A.T. (Aidana Tleuken); writing-review and editing, F.K. and A.T. (Ali Turkyilmaz); supervision, F.K.; project administration, F.K.; funding acquisition, F.K. and M.M. All authors have read and agreed to the published version of the manuscript.

Funding: The authors acknowledge the financial support from Nazarbayev University Faculty Development Competitive Research Grant Program (Funder Project Reference: 280720FD1904). This work is also supported by the Norwegian Agency for International Cooperation and Quality Enhancement in Higher Education (Diku) under Project ref. CPEA-ST-2019/10029: Academic Cooperation in Post-graduate Engineering Education (ACE) between UiT the Arctic University of Norway and Nazarbayev University, Kazakhstan. 
Institutional Review Board Statement: The study was conducted according to the guidelines of Research Ethics in Science and Technology and Procedures for Interview and Data Protection of Norwegian Arctic University (UiT).

Informed Consent Statement: Informed consent was obtained from all subjects involved in the study.

Conflicts of Interest: The authors declare no conflict of interest. The funders had no role in the design of the study; in the collection, analyses, or interpretation of data; in the writing of the manuscript, or in the decision to publish the results.

\section{Appendix A}

Table A1. ReSOLVE framework and survey questions.

\begin{tabular}{|c|c|c|c|c|c|c|c|}
\hline & & \multicolumn{6}{|c|}{ ReSOLVE Framework } \\
\hline & & REgenerate & Share & Optimize & Loop & Virtualize & Exchange \\
\hline \multirow{12}{*}{ 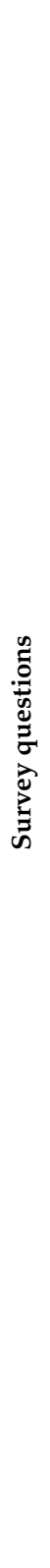 } & $\begin{array}{c}\text { Are you aware of the circular economy term and how it } \\
\text { applies to the construction industry? }\end{array}$ & $X$ & $X$ & $X$ & $X$ & $x$ & $X$ \\
\hline & $\begin{array}{l}\text { Is the demolition and/ or deconstruction process of the } \\
\text { structure (e.g., DfD concept) at the end of its life cycle } \\
\text { considered at the design stage? }\end{array}$ & $x$ & & $X$ & $X$ & & $x$ \\
\hline & $\begin{array}{l}\text { Different materials have different life cycles; do you } \\
\text { consider this for the building layering? E.g., insulation, } \\
\text { plaster, and facade in the exterior side of the building to be } \\
\text { nearly the same life-cycle, and plaster/drywall/wallpaper } \\
\text { in the interior to be nearly the same life-cycle. }\end{array}$ & $x$ & & $X$ & & & \\
\hline & $\begin{array}{l}\text { To what extent the design incorporates the materials that } \\
\text { are high-value recyclable where possible, e.g., steel, } \\
\text { gypsum drywalls, plywood, wooden blocks, etc., over } \\
\text { low-grade recyclable materials (e.g., concrete, bricks, etc.)? } \\
\text { quantity wise for all material in all projects during last ten } \\
\text { years }\end{array}$ & $x$ & & $X$ & $X$ & & $x$ \\
\hline & $\begin{array}{c}\text { Do you try to avoid "wet" building methods (e.g., welding, } \\
\text { sealing, gluing) over dry methods (bolting, coupling, } \\
\text { mechanical connections)? If yes, how? If no, what are the } \\
\text { barriers? }\end{array}$ & & & $X$ & $x$ & & $x$ \\
\hline & $\begin{array}{c}\text { How often are structures designed from prefabricated } \\
\text { blocks, modules that can be easily disassembled at the end } \\
\text { of their life cycle? (quantity-wise in all projects during last } \\
\text { ten years) }\end{array}$ & $X$ & & $X$ & $X$ & & $X$ \\
\hline & $\begin{array}{l}\text { During the design stage, is the floor space optimized by } \\
\text { designing for multipurpose areas (for public and } \\
\text { residential spaces), e.g., the dining area can be used as } \\
\text { office space or conference space etc. }\end{array}$ & & $X$ & $X$ & & $X$ & \\
\hline & $\begin{array}{l}\text { Does the design consider the potential to reduce waste of } \\
\text { construction materials and set objectives to minimize waste } \\
\text { where possible? }\end{array}$ & $x$ & & $x$ & $x$ & & \\
\hline & $\begin{array}{l}\text { To what extent used/second-hand/worn/refurbished } \\
\text { materials from existing or existing buildings are used in } \\
\text { the design of new buildings? }\end{array}$ & $X$ & & $x$ & $x$ & & $x$ \\
\hline & $\begin{array}{c}\text { To what extent is the restoration, refurbishing, and } \\
\text { adaptation of the existing structure preferred instead of its } \\
\text { demolition for a new project? (quantity-wise in all projects } \\
\text { during last ten years) }\end{array}$ & $x$ & & $x$ & $x$ & & $x$ \\
\hline & $\begin{array}{l}\text { Do you use building information modeling (BIM) during } \\
\text { design and optimize materials used where possible? }\end{array}$ & & & $x$ & $x$ & $x$ & \\
\hline & $\begin{array}{c}\text { To what extent biomaterials or organic materials (or Eco } \\
\text { materials in more general) are selected in the } \\
\text { architecture/design of the projects? }\end{array}$ & & & $x$ & $X$ & & \\
\hline
\end{tabular}




\section{References}

1. Bao, Z.; Lu, W.; Chi, B.; Yuan, H.; Hao, J. Procurement innovation for a circular economy of construction and demolition waste: Lessons learnt from Suzhou, China. Waste Manag. 2019, 99, 12-21. [CrossRef] [PubMed]

2. Gower, R.; Schröder, P. Virtuous circle: How the circular economy can create jobs and save lives in low and middle-income countries. Tearfund 2016, 6. Available online: https://www.researchgate.net/publication/306562812_Virtuous_Circle_how_the_ circular_economy_can_create_jobs_and_save_lives_in_low_and_middle-income_countries (accessed on 16 October 2021).

3. Adams, K.T.; Osmani, M.; Thorpe, T.; Thornback, J. Circular economy in construction: Current awareness, challenges and enablers. Proc. Inst. Civ. Eng. Waste Resour. Manag. 2017, 170, 15-24. [CrossRef]

4. Business in the Community (BITC). Advancing Circular Construction: Case Studies from the Building and Infrastructure sectors; BITC: London, UK, 2020.

5. Built-Env-Co.Project. Circularity in the Built Environment: Case Studies a Compilation of Case Studies from the CE100; Built-EnvCo.Project: Cowes, UK, 2016.

6. Chang, Y.-T.; Hsieh, S.-H. A Preliminary Case Study on Circular Economy in Taiwan's Construction. IOP Conf. Ser. Earth Environ. Sci. 2019, 225, 012069. [CrossRef]

7. Guerra, B.C.; Leite, F. Circular economy in the construction industry: An overview of United States stakeholders' awareness, major challenges, and enablers. Resour. Conserv. Recycl. 2021, 170, 105617. [CrossRef]

8. Press Service of the Prime Minister of the Republic of Kazakhstan. Kazakhstan, the Volume of Production of Building Materials Increased 3.3 Times. PrimeMinister.kz, 2020. Available online: https://primeminister.kz/ru/news/v-kazahstane-obemproizvodstva-stroitelnyh-materialov-uvelichilsya-v-33-raza-miir-rk-2161319 (accessed on 2 September 2021).

9. Turkyilmaz, A.; Guney, M.; Karaca, F.; Bagdatkyzy, Z.; Sandybayeva, A.; Sirenova, G. A comprehensive construction and demolition waste management model using PESTEL and 3R for construction companies operating in Central Asia. Sustainability 2019, 11, 1593. [CrossRef]

10. Press Service of the Prime Minister of the Republic of Kazakhstan. Housing Construction in Kazakhstan in 2020: Trends and Features. 2021. Available online: https://primeminister.kz/en/news/reviews/housing-construction-in-kazakhstan-in-2020 -trends-and-features (accessed on 26 June 2021).

11. Forbes.kz 17 Million Square Meters of Housing Are Promised to Be Built in 2021 in Kazakhstan. Available online: https: / / forbes.kz/news/2021/02/16/newsid_244035/?utm_source=forbes\&utm_medium=incut\&utm_campaign=news (accessed on 2 September 2021).

12. InBusiness.kz. Askar Mamin Instructed to Scale Modular Housing Construction in the Republic of Kazakhstan. 2021. Available online: https://inbusiness.kz/ru/news/askar-mamin-poruchil-masshtabirovat-modulnoe-domostroenie-v-rk (accessed on 21 June 2021).

13. Metabolic Analysis and Circular Economy Strategies for Almaty, Kazakhstan. Shifting Paradigms. 2019. Available online: https:/ / www.shiftingparadigms.nl/projects/almaty/ (accessed on 1 September 2021).

14. Zikrina, Z.; Urazayeva, F.; Cscp, N.V.; Fraser, M.; Douma, A.; Raspail, N. Almaty Circular Economy; Emerging Markets Sustainability Dialogue Challenge Fund: Almaty, Kazakhstan, 2019.

15. FABRICations. Almaty Circular Economy-Kazakhstan. 2019. Available online: https://www.fabrications.nl/portfolio-item/ almaty-circular-economy-kazakhstan/ (accessed on 1 September 2021).

16. Manninen, K.; Koskela, S.; Antikainen, R.; Bocken, N.; Dahlbo, H.; Aminoff, A. Do circular economy business models capture intended environmental value propositions? J. Clean. Prod. 2018, 171, 413-422. [CrossRef]

17. McKinsey Center for Business and Environment. The Circular Economy: Moving from Theory to Practice; McKinsey Center for Business and Environment: New York, NY, USA, 2016.

18. Frue, K. PEST Analysis Ultimate Guide: Definition, Template, Examples. 2020. Available online: https://pestleanalysis.com/ pest-analysis / (accessed on 20 June 2021).

19. Agency for Strategic Planning and Reforms of the Republic of Kazakhstan Bureau of National Statistics. Acting Legal Entities of All Size, Forms of Ownership, and Organizational and Legal Forms in Kazakhstan (as of May 2021). Available online: https:/ / stat.gov.kz/ (accessed on 1 September 2021).

20. Information on the Reduction, Recycling and Reuse of Waste. EGov. Government Services and Information Online. 2021. Available online: https:/ / egov.kz/cms/ru/articles/ecology/waste_reduction_recycling_and_reuse (accessed on 30 August 2021).

21. Press Service of the Prime Minister of the Republic of Kazakhstan. Mortgage on Favorable Terms and Construction of Affordable Housing-Development of Housing Construction in Kazakhstan. 2020. Available online: https://primeminister.kz/ru/ news / reviews / ipoteka-po-vygodnym-usloviyam-i-stroitelstvo-dostupnogo-zhilya-razvitie-zhilishchnogo-stroitelstva-vkazahstane-2861641 (accessed on 26 June 2021).

22. Coalition for Green Economy and Development G-Global. ‘Green' Economy as a Conscious Choice of Kazakhstan. Available online: https://greenkaz.org/index.php/press-centr/novosti-v-strane/item/3106-zelenaya-ekonomika-kak-osoznannyj-vyborkazakhstana (accessed on 30 June 2021).

23. Electronic labor stock “Enbek.kz". 2020. Available online: https://www.enbek.kz/atlas/ru/4/download-pdf (accessed on 17 October 2021). 
24. KURSIV. The Volume of Construction Work in Kazakhstan Since the Beginning of the Year Increased by 13.1\%. 2021. Available online: https:/ / kursiv.kz/news/otraslevye-temy/2021-04/obem-stroitelnykh-rabot-v-kazakhstane-s-nachala-goda-uvelichilsyana (accessed on 26 June 2021).

25. Press Service of the Prime Minister of the Republic of Kazakhstan. In 2021, Three New Projects will be Launched that Will Increase the Production of the Manufacturing Industry. 2021. Available online: https://primeminister.kz/ru/news/v-2021-godu-budutzapushcheny-tri-novyh-proekta-kotorye-uvelichat-obemy-proizvodstva-obrabatyvayushchey-otrasli-miir-162536 (accessed on 30 August 2021).

26. Forbes.kz. One Citizen of Kazakhstan Accounts for 21.9 sq. m of Living Space. 2020. Available online: https://forbes.kz/process / property/na_odnogo_kazahstantsa_prihoditsya_219_kv_m_jilploschadi (accessed on 26 June 2021).

27. Moura, M.C.P.; Smith, S.J.; Belzer, D.B. 120 Years of U.S. Residential Housing Stock and Floor Space. PLoS ONE 2015, 10, e0134135. [CrossRef] [PubMed]

28. ENTRANZE. Average Floor Area per Capita. Available online: https:/ / entranze.enerdata.net (accessed on 26 June 2021$).$

29. KURSIV. What Will Be the Construction Market in the Near Future. 2019. Available online: https://kursiv.kz/news/vlast-ibiznes/2019-06/kakim-budet-stroitelnyy-rynok-blizhayshego-buduschego (accessed on 26 June 2021).

30. Alimova, K. The Construction Market Is Experiencing an Acute Shortage of Personnel. InBusiness.kz, 2020. Available online: https:/ /inbusiness.kz/ru/news/rynok-stroitelstva-perezhivaet-ostryj-deficit-kadrov (accessed on 26 June 2021).

31. Kapitanova, I. Digital Technologies and Trends in Construction Were Discussed by the Participants of Digital Almaty-2021. Zakon.kz, 2021. Available online: https:/ / www.zakon.kz/5057237-tsifrovye-tehnologii-i-trendy-v.html (accessed on 26 June 2021).

32. Tumashova, E. Will BIM Technologies Change the Construction Industry in Kazakhstan? Kapital.kz, 2018. Available online: https:/ / kapital.kz/real_estate/66698/izmenyat-li-bim-tekhnologii-stroyotrasl-kazakhstana.html (accessed on 26 June 2021).

33. Modular vs Monolithic. We Compare Modern Technologies for Building Houses. Informburo.kz 2020. Available online: https: //informburo.kz/special/modulnoe-vs-monolitnoe-sravnivaem-sovremennye-tehnologii-stroitelstva-domov.html (accessed on 26 June 2021).

34. Vidyanova, A. Industrial Waste Recycling: Trends and New Opportunities. Kapital.kz, 2020. Available online: https:/ /kapital. kz/economic/91442/pererabotka-promyshlennykh-otkhodov-trendy-i-novyye-vozmozhnosti.html (accessed on 26 June 2021)

35. Futas, N.; Rajput, K.; Schiano-Phan, R. Cradle to Cradle and Whole-Life Carbon assessment - Barriers and opportunities towards a circular economic building sector. In Proceeding of the BAMB-CIRCPATH "Buildings as Material Banks-A Pathway For A Circular Future", Brussels, Belgium, 5-7 February 2019. [CrossRef]

36. Hart, J.; Adams, K.; Giesekam, J.; Tingley, D.D.; Pomponi, F. Barriers and drivers in a circular economy: The case of the built environment. Procedia CIRP 2019, 80, 619-624. [CrossRef]

37. Mahpour, A. Prioritizing barriers to adopt circular economy in construction and demolition waste management. Resour. Conserv. Recycl. 2018, 134, 216-227. [CrossRef]

38. Densley Tingley, D.; Cooper, S.; Cullen, J. Understanding and overcoming the barriers to structural steel reuse, a UK perspective. J. Clean. Prod. 2017, 148, 642-652. [CrossRef]

39. Akinade, O.; Oyedele, L.; Oyedele, A.; Davila Delgado, J.M.; Bilal, M.; Akanbi, L.; Ajayi, A.; Owolabi, H. Design for deconstruction using a circular economy approach: Barriers and strategies for improvement. Prod. Plan. Control 2020, 31, 829-840. [CrossRef]

40. Sigrid Nordby, A. Barriers and opportunities to reuse of building materials in the Norwegian construction sector. In Proceedings of the BAMB-CIRCPATH “Buildings as Material Banks-A Pathway for A Circular Future”, Brussels, Belgium, 5-7 February 2019. [CrossRef]

41. Debacker, W.; Manshoven, S. D1 Synthesis of the State-of- the-Art Key Barriers and Opportunities for Materials Passports and Reversible Building Design in the Current System; BAMB: Brussels, Belgium, 2016.

42. Munaro, M.R.; Tavares, S.F.; Bragança, L. Towards circular and more sustainable buildings: A systematic literature review on the circular economy in the built environment. J. Clean. Prod. 2020, 260, 121134. [CrossRef]

43. Rahla, K.; Mateus, R.; Bragança, L. Implementing Circular Economy Strategies in Buildings—From Theory to Practice. Appl. Syst. Innov. 2021, 4, 26. [CrossRef]

44. Liu, Z.; Osmani, M.; Demian, P.; Baldwin, A. The Potential Use of BIM to Aid Construction Waste Minimisation; Creative Commons: Loughborough, UK, 2011.

45. Mangialardo, A.; Micelli, E. Rethinking the Construction Industry Under the Circular Economy: Principles and Case Studies; Springer: Berlin, Germany, 2018. [CrossRef]

46. Morel, J.C.; Charef, R. What are the barriers affecting the use of earth as a modern construction material in the context of circular economy? In Proceedings of the BAMB-CIRCPATH "Buildings as Material Banks-A Pathway for A Circular Future", Brussels, Belgium, 5-7 February 2019. [CrossRef]

47. Ding, Z.; Zhu, M.; Tam, V.W.Y.; Yi, G.; Tran, C.N.N. A system dynamics-based environmental benefit assessment model of construction waste reduction management at the design and construction stages. J. Clean. Prod. 2018, 176, 676-692. [CrossRef] 